\title{
Proteomic analysis of black poplar (Populus nigra L.) seed storability
}

\author{
Tomasz A. Pawłowski $^{1}$ (D) • Ewelina A. Klupczyńska ${ }^{1}$ - Aleksandra M. Staszak ${ }^{1}$ - Jan Suszka ${ }^{1}$
}

Received: 7 May 2019 / Accepted: 24 September 2019 / Published online: 29 October 2019

(C) The Author(s) 2019

\begin{abstract}
- Key message Adequate storability of black poplar (Populus nigra L.) seeds at temperatures below $0{ }^{\circ} \mathrm{C}$ was associated with preservation of proteins of energy and carbohydrate metabolism, protein turnover, and proteins maintaining longterm stability of dehydrated tissue.

- Context Understanding seed storability is a key factor for effective seed preservation and conservation. Black poplar is an endangered tree species and its seed loses rapidly viability during storage.

- Aims The aim of this study was to determine, and functionally characterise, the proteins associated with storability of black poplar seeds.

- Methods Dried seeds $(7.1 \% \mathrm{MC})$ were stored at $3{ }^{\circ} \mathrm{C},-3{ }^{\circ} \mathrm{C},-20^{\circ} \mathrm{C}$, and $-196{ }^{\circ} \mathrm{C}$, for a period of 12 and 24 months. Proteins were extracted and separated according to their isoelectric point $(\mathrm{p} I)$ and mass using 2-dimensional electrophoresis. Proteins that varied in abundance for temperature and time of storage were identified by mass spectrometry.

- Results A germination test showed that seeds remained viable at $-3,-20$, and $-196{ }^{\circ} \mathrm{C}$. Storage at $3{ }^{\circ} \mathrm{C}$ caused loss of seed viability. This loss in seed vigour was related to the largest changes in protein abundance. As storage temperature decreased, a smaller number of proteins displayed changed abundance.

- Conclusion Good storability of black poplar seeds under freezing conditions may be associated with the following: an inhibition of synthesis of energy and carbohydrate metabolism and protein turnover proteins, LEA proteins that maintain long-term stability of dehydrated tissue, GDSL esterases/lipases that inhibit hydrolysing activity, and by chaperonins that protect protein functionality. Storage conditions influence the preservation of protein function that governs seed viability.
\end{abstract}

Keywords Chilling stress $\cdot$ Germination $\cdot$ Longevity $\cdot$ Proteomics $\cdot$ Seed viability $\cdot$ Seed vigour

\section{Introduction}

Preservation of genetic diversity is one of the major issues in seed science. Seed longevity, the period over which seeds remain viable, is an important trait for plant adaptation to changing

Contribution of the co-authors Conceptualization: TAP, JS; methodology: TAP, AMS, JS; software: TAP, EAK, AMS; validation: TAP, EAK, AMS; formal analysis: TAP, EAK, AMS, JS; investigation: AMS, TAP; resources: JS, TAP; data curation: TAP, EAK, AMS; writing-original draft: TAP; writing-review and editing: TAP, EAK, AMS, JS; visualisation: TAP, EAK, AMS, JS; supervision: TAP; project administration: JS; funding acquisition: JS

Handling Editor: Andrew Merchant

Tomasz A. Pawłowski

tapawlow@man.poznan.pl

1 Institute of Dendrology, Polish Academy of Sciences, Kórnik, Poland environments and conservation of biodiversity (Sano et al. 2016). Seed longevity largely relies on the viability of embryo (Sano et al. 2016). Black poplar (Populus nigra L.) produces short-lived seeds, classified as intermediate (Suszka et al. 2014; Michalak et al. 2015). This tree forms a vital part of floodplain forest ecosystems (Wyckoff and Zasada 2005). It is very important to preserve genetic material due to the devastation of these habitats, with black poplar in particular being one of the most threatened tree species in Europe (Suszka et al. 2014).

Proteomic approaches enable the evaluation of protein markers which can be useful in determination of optimal storage conditions (Baginsky 2009). Protein markers can give information about physiological changes occurring during seed conservation, and about the condition of stored seeds. Changes in the proteome can show otherwise invisible signs of seed deterioration, what can be useful in predication of loss of seed vigour. Such a loss of vigour precedes the loss of the ability to germinate (van de Venter 2001). The germination tests do not reflect adequately the degree of seed deterioration 
(van de Venter 2001). Proteomic research has mainly concentrated on the negative influence of external and internal factors causing loss of seed viability (see for review Wang et al. 2015), such as drying (Rajjou and Debeaujon 2008), high temperature (Zhang and Li 2015; Chen et al. 2016), and high humidity and temperature (ageing) (Rajjou et al. 2008; Kalemba and Pukacka 2014; Nguyen et al. 2015; Zhang et al. 2015; Li et al. 2017; Yin et al. 2017). Proteomic data has shown that reduction of seed longevity is often associated with oxidation of cellular macromolecules such as nucleic acids, proteins, and lipids (Sano et al. 2016). Gao et al. (2016) indicated that redox regulation proteins, mainly glutathione-related proteins, and defence proteins, including DNA-damage-repair proteins, and a late embryogenesis abundant (LEA) protein might have positive influence on seed storability. Min et al. (2017) also highlighted the positive role of antioxidant enzymes dehydroascorbate reductase (DHAR), ascorbate peroxidase (APX), and superoxide dismutase (SOD), as well as peroxiredoxin, for seed longevity (Yin et al. 2015). Nguyen et al. (2015) confirmed the role of antioxidant systems, and additionally illustrated the role of translation machinery and energy pathways in seed longevity. Yin et al. (2017) showed that loss of seed viability is also associated with a decrease in heat shock proteins. For elm (Ulmus pumila L.), it was found that increased production of ROS during seed ageing induced alteration of specific mitochondrial proteins that may be involved in the process of mitochondrial deterioration, which led to loss of seed viability (Li et al. 2017). These data concerned generally seeds exposed to ageing protocols which were based on high-humidity and high-temperature storage conditions. The present study illustrates the influence of low temperatures, including cryopreservation, on seed viability and protein composition.

Tree seed quality, development, and germination have been considered using proteomic approaches (Staszak and Pawłowski 2014; Pawłowski and Staszak 2016; Staszak et al. 2019). In the present study, proteome changes were investigated in black poplar seeds under different storage conditions (temperature and time), to reveal differentially abundant proteins, in order to identify those putatively responsible for successful storability and stress resistance. We hypothesised that the preservation of black poplar seeds is accounted for by the smallest changes in protein abundance variability, and seed vitality is associated with proteins maintaining primary metabolism, protein and dehydrated tissue stability.

\section{Material and methods}

\subsection{Plant material and experimental design}

Mature seeds enclosed in catkins were collected from several trees of black poplar (Populus nigra L.) growing in floodplains located near Czeszewo, Poland (N 52 ${ }^{\circ} 8^{\prime}$ and E $17^{\circ} 30^{\prime}$ ) in 2010 (27 May-16 June). After collection, catkins were placed in an environmental chamber at a constant temperature of $15^{\circ} \mathrm{C}$ for $72 \mathrm{~h}$ to promote full opening. Seeds were then separated from cotton.

\subsection{Desiccation of seeds}

Freshly extracted seeds had a water content (WC) in the range of $0.14-0.17 \mathrm{~g} \mathrm{H}_{2} \mathrm{O} \mathrm{g}^{-1}$ dry mass $\left(\mathrm{g} \mathrm{g}^{-1}\right)$, which represents a moisture content (MC) of 12.5-14.4\% on a fresh weight basis. Prior to storage, seeds were dried in a seed dryer at $20^{\circ} \mathrm{C}$ for about $1 \mathrm{~h}$ to $0.071 \mathrm{~g} \mathrm{~g}^{-1}(7.1 \% \mathrm{MC})$. Seed WC ( 3 replications of 50 seeds each) was determined by drying seeds at $103 \pm$ $2{ }^{\circ} \mathrm{C}$ for $17 \mathrm{~h}$ (ISTA 2013).

\subsection{Seed storage conditions}

Details of the storage protocols were described in Suszka et al. (2014). Briefly, desiccated seeds were stored at different temperatures: $3{ }^{\circ} \mathrm{C},-3{ }^{\circ} \mathrm{C},-20{ }^{\circ} \mathrm{C}$ in cold rooms. Seeds were packed in tightly closed polyethylene vials during storage. Seeds were also cryostored at $-196{ }^{\circ} \mathrm{C}$ in liquid nitrogen. After storage in liquid $\mathrm{N}$, seeds in the cryovials were thawed at $40{ }^{\circ} \mathrm{C}$ in a water bath for $5 \mathrm{~min}$. Seeds were stored conventionally for a period of 12 and 24 months, and in liquid $\mathrm{N}$ for 24 months. The controls were desiccated non-stored seeds. The germination test was performed on four samples of 100 seeds each as described by Suszka et al. (2014). Analysis of variance (ANOVA) and a Tukey-Kramer HSD was used to assess the influence of storage temperature and time on the level of seed germination, at $p<0.05$ (JMP software, SAS Institute, Cary, NC, USA). Details of the results of statistical analysis, because of the use of the same batch of seeds in present and that study, were described in Suszka et al. (2014).

\subsection{Protein extraction}

All analyses were conducted using four biological replicates. Proteins were extracted and precipitated overnight at $-20^{\circ} \mathrm{C}$ in a $10 \%(\mathrm{w} / \mathrm{v})$ solution of TCA in acetone containing $20 \mathrm{mM}$ dithiothreitol (DTT) (Pawłowski 2009). After centrifugation $\left(16,000 \mathrm{~g}\right.$ for $5 \mathrm{~min}$ at $4^{\circ} \mathrm{C}$ ), the resulting pellets were washed three times with $1 \mathrm{ml}$ of acetone supplemented with $20 \mathrm{mM}$ DTT and were then re-centrifuged. After vacuum drying, pellets were suspended in lysis buffer (7 M urea, $2 \mathrm{M}$ thiourea, $2 \%$ [w/v] CHAPS, $1.5 \%$ [w/v] DTT, $0.5 \%$ [v/v] IPG buffer $\mathrm{pH}$ 4-7, supplemented with a Protease Inhibitor Cocktail (Roche, Mannheim, Germany) according to the manufacturer's suggestions. Protein concentrations were determined using the Bradford assay (Ramagli and Rodriguez 1985). 


\subsection{Protein electrophoresis, 2-DE IEF/SDS-PAGE}

Proteins $(600 \mu \mathrm{g}$ for colloidal Coomassie Blue) were first separated according to their isoelectric point on rehydrated Immobiline dry strips $(24 \mathrm{~cm}$, with a linear $\mathrm{pH}$ gradient of 4-7) in rehydration buffer (6 $\mathrm{M}$ urea, $2 \mathrm{M}$ thiourea, $2 \%$ [w/v] CHAPS, $20 \mathrm{mM}[\mathrm{w} / \mathrm{v}]$ DTT, 0.5\% [v/v] IPG buffer $\mathrm{pH}$ 4-7) using an Ettan IPGphor 3 IEF System (GE Healthcare). The electrophoresis program used for isoelectrofocusing was according to the manufacturer's directions for 24-cm strips. The strips containing the separated proteins were immersed in equilibration solution I (6 M urea, $1.5 \mathrm{M}$ Tris- $\mathrm{HCl}, \mathrm{pH} 8.8,30 \%$ [v/v] glycerol, $2 \%$ [w/v] SDS, $1 \%[\mathrm{w} / \mathrm{v}] \mathrm{DTT}$ ) and then in equilibration solution II (equilibration solution I supplemented with $2.5 \%[\mathrm{w} / \mathrm{v}]$ iodoacetamide, without DTT) for $10 \mathrm{~min}$ and subjected to second dimension (SDS-PAGE) separation.

Pre-cast Ettan DALT 12.5\% (w/v) polyacrylamide gels (GE Healthcare) and the Ettan Dalt Six electrophoresis chamber (capable of processing six gels) were used for SDS-PAGE. Conditions were as follows: $1 \mathrm{~h}$ at $80 \mathrm{~V}$ and $5 \mathrm{~h}$ at $500 \mathrm{~V}$. A mixture of molecular weight markers (GE Healthcare) was loaded next to the Immobiline strip. Four replicate gels were run for every treatment $(n=4)$. After electrophoresis, the gels were stained with colloidal Coomassie blue, which, in addition to visualisation and quantification, also allowed MS analyses (Neuhoff et al. 1988).

\subsection{Gel analysis}

The gels were scanned and analysed using 2D Image Master 7 Platinum software (GE Healthcare). After spot detection, gels from the four independent biological samples were aligned, and normalized spot volumes of the identified spots were determined. Spots with variations in abundance (statistics between gel sets/classes, i.e. central tendency, dispersion, and overlapping measures was used) were subjected to ANOVA and a Tukey-Kramer HSD test (JMP software, SAS Institute, Cary, NC, USA) to select spots that significantly varied $(p<$ 0.05 ) in abundance for two factors: temperature and time of storage. Fold change was calculated for temperature influence as $\log _{2}$ (Meunier et al. 2005). The significantly variable proteins were subsequently identified by MS.

\subsection{Mass spectrometry}

The gel spots were subjected to a standard "in-gel digestion" procedure in which proteins were reduced with $10 \mathrm{mM}(\mathrm{w} / \mathrm{v})$ DTT (for $30 \mathrm{~min}$ at $56{ }^{\circ} \mathrm{C}$ ), alkylated with $55 \mathrm{mM}$ iodoacetamide (45 $\mathrm{min}$ in the dark at room temperature) and digested overnight with trypsin (Sequencing Grade Modified Trypsin, Promega V5111) in $25 \mathrm{mM}$ ammonium bicarbonate
(25 ng $\mathrm{Hl}^{-1}$ of trypsin). The resulting peptides were eluted from the gel matrix with $0.1 \%(\mathrm{v} / \mathrm{v})$ TFA in $2 \%(\mathrm{v} / \mathrm{v}) \mathrm{ACN}$.

Peptide mixtures were analysed by liquid chromatography coupled to the mass spectrometer in the Laboratory of Mass Spectrometry, Institute of Biochemistry and Biophysics, Polish Academy of Sciences (Warsaw, Poland). Samples were concentrated and desalted on a RP-C18 pre-column (nanoACQUITY Symmetry ${ }^{\circledR}$ C18, Waters), and further peptide separation was achieved on a nano-Ultra Performance Liquid Chromatography (UPLC) RP-C18 column (Waters, BEH130 C18 column, $75 \mu \mathrm{m}$ i.d., $250 \mathrm{~mm}$ long) of a nanoACQUITY UPLC system, using a linear acetonitrile gradient $(0-60 \%[\mathrm{v} / \mathrm{v}] \mathrm{ACN}$ for $120 \mathrm{~min}$.) in the presence of $0.05 \%(\mathrm{v} / \mathrm{v})$ formic acid with a flow rate of $150 \mathrm{nl} / \mathrm{min}$. The column outlet was directly coupled to the Electrospray Ionization (ESI) ion source of the Orbitrap Velos type mass spectrometer (Thermo Electron Corp., San Jose, CA, USA), working in the regime of data-dependent MS to MS/MS switch. An electrospray voltage of $1.5 \mathrm{kV}$ was used. A blank run preceded each analysis ensuring lack of cross contamination from previous samples.

\subsection{Protein identification and classification}

The mascot search algorithm (http://www.matrixscience.com) was used for protein identification against the NCBInr (http:// www.ncbi.nig.gov) databases. Protein identification was performed using the Mascot search probability-based molecular weight search-MOWSE score. Ions score was $-10 \times \log (P)$, where $P$ was the probability that the observed match was a random event. Peptides with a Mascot score exceeding the threshold value corresponding to $<5 \%$ false positive rate, calculated by the Mascot procedure, were considered to be positively identified.

Identified proteins were grouped due to biological process, molecular function, and subcellular localization according to the gene ontology (GO) annotation using UniProt database and QuickGO search (https://www.ebi.ac.uk/QuickGO/). A Venn diagram of protein quantification according to seed storage condition was prepared using Bioinformatics and Evolutionary Genomics tool (http://bioinformatics.psb.ugent. be/webtools/Venn/).

\section{Results}

Effect of storage time and temperature on black poplar seed germination is illustrated in Fig. 1. Germination ability was highest after seed storage at $-20^{\circ} \mathrm{C}$ for 1 year as well as for 2 years. A slight decrease in germination, which was not statistically significant, was indicated in seeds stored for 1 and 2 years at $-3{ }^{\circ} \mathrm{C}$. A significant decrease in germination was observed after 1 year, and even more so after 2 years of seed storage at $3{ }^{\circ} \mathrm{C}$. 


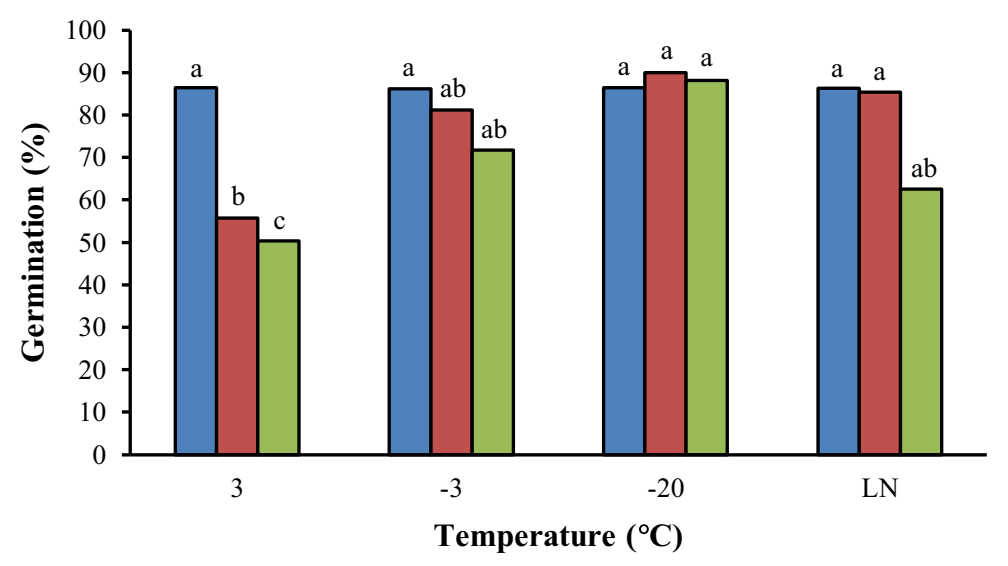

storage time (months) $\square 0 \square 12 \square 24$

Fig. 1 Effect of storage time and temperature on Populus nigra L. seed germination as a function of time (0, 12, 24 months) and temperature (3,-3,$20,-196{ }^{\circ} \mathrm{C}$ ). Data with different letters are significantly different, $p<0.05$ (Suszka et al. 2014, with modification)

An average of 420 Coomassie blue stained spots was detected on each gel using Image Master 7 Platinum software. A total of 37 spots exhibiting significant changes in volume (i.e. abundance), representing approximately $9 \%$ of the total number of spots on a reference gel (Fig. 2), were identified by MS.

Among the 37 identified proteins (Table 1; Fig. 2), 19 increased and 18 decreased in abundance under the influence of storage temperature, compared with the control (ANOVA, the
Tukey-Kramer HSD test, and fold change). Twenty five proteins were variable for $3{ }^{\circ} \mathrm{C}(14$ increased and 11 decreased in abundance), 16 proteins for $-3{ }^{\circ} \mathrm{C}$ (half increased and half decreased in abundance), 13 proteins for $-20^{\circ} \mathrm{C}$ ( 4 increased and 9 decreased in abundance), and 3 proteins for $-196^{\circ} \mathrm{C}(2$ increased and 1 decreased in abundance). One protein was variable in abundance for time of storage (it decreased after 1 year) and 9 for time and temperature (3 increased and 6
Fig. 2 Reference gel presenting positions of statistically variable spots from Populus nigra L. seeds stored at different temperature conditions of $3,-3,-20$, and $196{ }^{\circ} \mathrm{C}$ for 12 and 24 months. The numbers of identified proteins correspond to those listed in Table 1. Spots which increased in abundance under the influence of temperature in comparison with control are marked in green; spots which decreased in abundance are marked in red

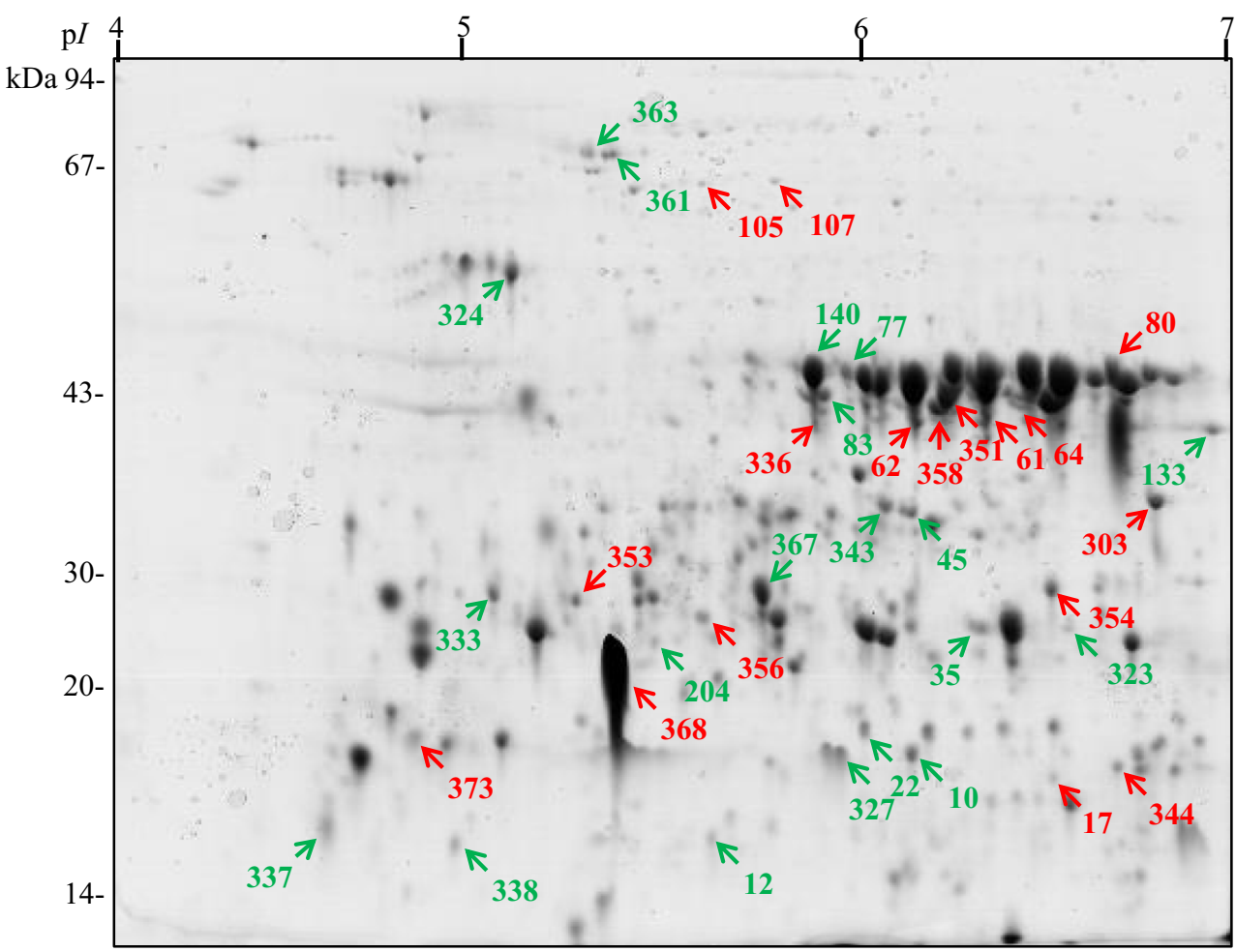


Table 1 Identification of differentially abundant proteins of Populus nigra seeds stored in different temperature $\left(3,-3,-20\right.$, and $\left.-196^{\circ} \mathrm{C}(\mathrm{LN})\right)$ and time (12 and 24 months) conditions

\begin{tabular}{|c|c|c|c|c|c|c|c|c|c|c|c|c|c|c|c|c|c|}
\hline \multirow{3}{*}{ Spot $^{\text {a }}$} & \multirow{3}{*}{ Protein ${ }^{b}$} & \multirow{3}{*}{ Species } & \multirow{3}{*}{ Accession $^{c}$} & \multicolumn{7}{|c|}{ Fold change ${ }^{d}$} & \multirow{3}{*}{$\begin{array}{l}\text { Observed } \\
\mathrm{MW} / \mathrm{p} I\end{array}$} & \multirow{3}{*}{$\begin{array}{c}\text { Theoretical } \\
\mathrm{MW} / \mathrm{p} I\end{array}$} & \multirow{3}{*}{ Score } & \multirow{3}{*}{$\mathrm{SC}^{\mathrm{e}}$} & \multirow{3}{*}{$\begin{array}{l}\text { All/ } / \text { no } \\
\text { repeat }^{f}\end{array}$} & \multirow{3}{*}{$\begin{array}{l}\text { Unic/no } \\
\text { repeat }{ }^{8}\end{array}$} & \multirow{3}{*}{ emPAI } \\
\hline & & & & $3^{\circ} \mathrm{C}$ & $3^{\circ} \mathrm{C}$ & $-3^{\circ} \mathrm{C}$ & $-3^{\circ} \mathrm{C}$ & $-20^{\circ} \mathrm{C}$ & $-20^{\circ} \mathrm{C}$ & LN & & & & & & & \\
\hline & & & & 12 & 24 & 12 & 24 & 12 & 24 & 24 & & & & & & & \\
\hline \multicolumn{18}{|c|}{ Metabolic process ${ }^{\mathrm{i}}$} \\
\hline 10 & $\begin{array}{l}\text { subtilisin-like protease } \\
\text { SBT3.3 }\end{array}$ & $\begin{array}{l}\text { Populus. } \\
\text { trichocarpa }\end{array}$ & XP_006371466 & 2.4 & 1.4 & 0.0 & 0.0 & 1.5 & 0.4 & -0.3 & $19 / 6.08$ & $11 / 5.85$ & 445 & 61 & $6 / 6$ & $3 / 3$ & 8.92 \\
\hline 12 & arginase 1 & P. trichocarpa & XP_002320051 & 2.6 & 1.6 & 2.6 & 2.9 & 1.5 & 2.6 & 3.2 & $16 / 5.66$ & $37 / 5.73$ & 187 & 7 & $6 / 2$ & $6 / 2$ & 0.28 \\
\hline 17 & $\begin{array}{l}\text { nucleoside diphosphate } \\
\text { kinase } 1\end{array}$ & P. euphratica & XP_011032405 & -1.0 & -2.4 & -0.8 & -1.0 & 2.1 & 1.2 & -2.1 & $18 / 6.51$ & $16 / 6.09$ & 258 & 26 & $8 / 3$ & $8 / 3$ & 1.16 \\
\hline 22 & $\begin{array}{l}\text { Kunitz-type protease } \\
\text { inhibitor KPI-D2.3 }\end{array}$ & P. euphratica & ACS92509 & 1.5 & 1.5 & 1.2 & 0.7 & 0.7 & 0.0 & 1.5 & $22 / 5.98$ & $24 / 5.48$ & 249 & 17 & $4 / 3$ & $4 / 3$ & 0.72 \\
\hline 45 & $\begin{array}{l}\text { pyruvate dehydrogenase } \\
\text { E1 }\end{array}$ & P. trichocarpa & XP_002311788 & 1.3 & 0.9 & 0.3 & 0.4 & -0.2 & 0.4 & 0.7 & $34 / 6.13$ & $44 / 8.05$ & 358 & 11 & $6 / 5$ & $2 / 2$ & 0.48 \\
\hline 61 & $\begin{array}{l}\text { fructose-bisphosphate } \\
\text { aldolase 3, chloroplastic }\end{array}$ & $\begin{array}{l}\text { Citrus } \\
\text { clementina }\end{array}$ & XP_006448338 & -0.4 & 0.8 & -0.3 & 0.7 & -0.5 & -0.2 & -0.1 & $38 / 6.32$ & $43 / 8.13$ & 500 & 19 & $8 / 7$ & $1 / 1$ & 0.98 \\
\hline 62 & $\begin{array}{l}\text { fructose-bisphosphate } \\
\text { aldolase }\end{array}$ & P. euphratica & XP_011043938 & 0.8 & -1.1 & 0.7 & 0.9 & 0.6 & -0.4 & -0.1 & $38 / 6.14$ & $39 / 7.01$ & 763 & 31 & $13 / 8$ & $8 / 4$ & 1.40 \\
\hline 77 & $\begin{array}{l}\text { isoflavone reductase } \\
\text { family protein }\end{array}$ & P. trichocarpa & XP_002313788 & 0.7 & 1.1 & 0.4 & 0.7 & 0.1 & 0.4 & -0.2 & $44 / 5.96$ & $34 / 6.02$ & 635 & 27 & $16 / 9$ & $0 / 0$ & 2.19 \\
\hline 80 & $\begin{array}{l}\text { glyceraldehyde-3- } \\
\text { phosphate dehydrogenase }\end{array}$ & $\begin{array}{l}\text { Antirrhinum } \\
\text { majus }\end{array}$ & P25861 & -0.7 & -0.5 & -0.7 & -0.5 & 0.8 & -1.2 & -1.1 & $42 / 6.70$ & $37 / 8.30$ & 313 & 12 & $5 / 4$ & $0 / 0$ & 0.42 \\
\hline 83 & enoyl-ACP reductase & $\begin{array}{l}\text { Malus } \\
\text { domestica }\end{array}$ & 008361462 & 1.4 & 1.0 & 0.8 & 0.9 & 0.9 & 1.2 & 1.3 & $42 / 5.90$ & $42 / 8.52$ & 404 & 15 & $11 / 5$ & $6 / 3$ & 1.03 \\
\hline 105 & $\begin{array}{l}\text { ATP synthase subunit } \\
\text { beta }\end{array}$ & P. trichocarpa & XP_002315902 & 0.6 & -0.3 & 0.0 & 0.1 & -0.2 & -0.4 & 0.0 & $66 / 5.55$ & $60 / 5.96$ & 1639 & 41 & $76 / 18$ & $10 / 3$ & 3.35 \\
\hline 107 & $\begin{array}{l}\text { aldehyde dehydrogenase } \\
\text { family } 2 \text { member B7 }\end{array}$ & P. trichocarpa & XP_002301540 & -1.9 & -1.3 & -1.0 & -1.7 & -1.0 & -0.9 & -0.9 & $66 / 5.79$ & $59 / 6.11$ & 1485 & 34 & $57 / 18$ & $23 / 7$ & 2.29 \\
\hline 133 & malate dehydrogenase & P. trichocarpa & XP_002312583 & -1.2 & -0.5 & -1.1 & -0.2 & 0.7 & -0.3 & -0.8 & $36 / 6.95$ & $36 / 6.11$ & 800 & 27 & $17 / 9$ & $11 / 6$ & 1.56 \\
\hline 140 & $\begin{array}{l}\text { enolase } \\
\text { glyceraldehyde-3- }\end{array}$ & Vitis vinifera & XP_002267091 & 3.8 & 3.0 & 2.9 & 3.3 & 3.3 & 3.5 & 2.3 & $43 / 5.88$ & $48 / 6.17$ & 836 & 24 & $15 / 9$ & $0 / 0$ & 1.22 \\
\hline 303 & $\begin{array}{l}\text { phosphate dehydrogenase } \\
2\end{array}$ & P. trichocarpa & XP_002318114 & -0.3 & -0.2 & -0.1 & 0.0 & -0.3 & 0.6 & 0.0 & $30 / 6.71$ & $37 / 6.34$ & 299 & 10 & $9 / 4$ & $7 / 2$ & 0.43 \\
\hline 333 & $\begin{array}{l}\text { glutathione S-transferase } \\
\text { F11 }\end{array}$ & P. trichocarpa & XP_002301942 & 1.7 & 1.8 & 1.5 & 1.5 & 1.3 & 1.4 & 1.3 & $26 / 4.95$ & $25 / 5.52$ & 308 & 24 & $12 / 5$ & $7 / 4$ & 1.35 \\
\hline 343 & $\begin{array}{l}\text { DHAR class glutathione } \\
\text { transferase DHAR2 }\end{array}$ & P. trichocarpa & ADB11344 & 2.3 & 1.7 & 1.5 & 1.7 & 1.9 & 2.0 & 2.0 & $33 / 6.06$ & $24 / 5.53$ & 409 & 33 & $10 / 6$ & $10 / 6$ & 1.98 \\
\hline 351 & GDSL esterase/lipase & P. trichocarpa & XP_002300062 & 0.6 & 0.6 & 1.0 & -2.1 & -0.2 & 1.2 & 1.2 & $42 / 6.24$ & $43 / 6.15$ & 227 & 10 & $6 / 4$ & $6 / 4$ & 0.49 \\
\hline 368 & $\begin{array}{l}\text { ribulose-1.5-bisphosphate } \\
\text { carboxylase/oxygenase } \\
\text { large subunit }\end{array}$ & $\begin{array}{l}\text { Piper } \\
\text { carrilloanum }\end{array}$ & ACX61904 & -0.1 & 0.1 & 0.0 & -0.2 & 0.6 & -0.2 & -0.3 & $25 / 5.28$ & $21 / 5.95$ & 349 & 17 & $11 / 5$ & $4 / 1$ & 1.75 \\
\hline \multicolumn{18}{|c|}{$\begin{array}{l}\text { Cellular process } \\
\text { eukaryotic translation }\end{array}$} \\
\hline 64 & $\begin{array}{l}\text { initiation factor } 3 \text { subunit } \\
\text { I-like }\end{array}$ & P. euphratica & XP_011024978 & 0.2 & -0.6 & 0.7 & -1.2 & -0.6 & -0.4 & -0.9 & $40 / 6.42$ & $36 / 6.37$ & 684 & 28 & $12 / 7$ & $4 / 1$ & 1.33 \\
\hline 344 & $\begin{array}{l}\text { ubiquitin-conjugating } \\
\text { enzyme E2 } 35 \text { isoform X2 }\end{array}$ & P. trichocarpa & XP_002316867 & 1.2 & 2.0 & -0.1 & -1.0 & 0.1 & -0.9 & -0.4 & $19 / 6.76$ & $17 / 6.74$ & 290 & 34 & $7 / 4$ & $3 / 2$ & 1.71 \\
\hline 353 & $\begin{array}{l}20 \mathrm{kDa} \text { chaperonin family } \\
\text { protein }\end{array}$ & P. trichocarpa & XP_002324138 & 0.7 & -0.4 & 0.1 & -0.4 & -0.6 & -0.1 & 0.0 & $26 / 5.18$ & $27 / 7.77$ & 616 & 36 & $15 / 7$ & $9 / 4$ & 1.99 \\
\hline 358 & transport protein $\mathrm{SEC} 13$ & P. trichocarpa & XP_002315836 & -0.5 & -0.4 & 0.7 & -0.5 & -0.8 & 0.4 & 0.0 & $39 / 6.19$ & $33 / 5.67$ & 383 & 19 & $11 / 5$ & $4 / 1$ & 0.93 \\
\hline 361 & $\begin{array}{l}\text { chaperonin CPN60-2, } \\
\text { mitochondrial-like } \\
\text { isoform X1 }\end{array}$ & P. euphratica & XP_011020718 & 0.8 & 1.0 & 1.0 & 1.1 & 0.6 & 1.0 & 1.3 & $76 / 5.28$ & $61 / 7.88$ & 1133 & 30 & $20 / 15$ & $0 / 0$ & 2.02 \\
\hline 363 & $\begin{array}{l}\text { chaperonin } 60 \text { subunit } \\
\text { beta } 2 \text {, chloroplastic }\end{array}$ & P. trichocarpa & XP_002297617 & 0.5 & 0.6 & 0.9 & 0.8 & 0.5 & 0.6 & 0.7 & $77 / 5.23$ & $64 / 5.62$ & 1017 & 23 & $19 / 13$ & $14 / 9$ & 1.56 \\
\hline 373 & $\begin{array}{l}\text { 60S ribosomal protein } \\
\text { L22-1 }\end{array}$ & P. trichocarpa & XP_002321184 & -0.5 & -0.4 & -0.4 & -0.7 & -0.4 & 0.8 & -0.6 & $19 / 4.66$ & $14 / 9.57$ & 252 & 29 & $7 / 3$ & $0 / 0$ & 1.68 \\
\hline \multicolumn{18}{|c|}{ Response to stimulus } \\
\hline 204 & $\begin{array}{l}\text { temperature-induced } \\
\text { lipocalin }\end{array}$ & P. euphratica & ACJ02358 & 1.8 & 1.1 & 0.6 & 0.8 & 0.2 & 0.1 & -0.4 & $24 / 5.40$ & $22 / 5.73$ & 651 & 32 & $16 / 7$ & $16 / 7$ & 2.21 \\
\hline 323 & dehydrin DHN 3 & P. euphratica & XP_011034314 & 3.5 & 2.9 & 3.5 & 3.2 & 4.0 & 2.4 & 0.4 & $25 / 6.56$ & $14 / 8.65$ & 345 & 26 & $17 / 5$ & $16 / 4$ & 5.85 \\
\hline 327 & glutaredoxin $\mathrm{C} 4$ & P. trichocarpa & XP_002325236 & 3.3 & 2.0 & 0.3 & 2.2 & 1.7 & 1.8 & 2.1 & $20 / 5.93$ & $15 / 5.77$ & 255 & 38 & $5 / 4$ & $2 / 1$ & 2.09 \\
\hline 337 & $\begin{array}{l}\text { seed maturation protein } \\
\text { PM22 }\end{array}$ & P. trichocarpa & XP_002320161 & 1.7 & 1.2 & 0.6 & -0.6 & -0.4 & 0.3 & 0.7 & $16 / 4.28$ & $17 / 4.60$ & 397 & 39 & $10 / 5$ & $10 / 5$ & 2.70 \\
\hline 338 & $\begin{array}{l}\text { universal stress protein } \\
\text { PHOS32 }\end{array}$ & P. trichocarpa & XP_006373900 & 0.6 & 0.1 & 0.2 & 0.0 & 0.0 & -0.4 & 0.1 & $16 / 4.83$ & $18 / 5.20$ & 311 & 27 & $19 / 4$ & $19 / 4$ & 0.95 \\
\hline 356 & $\begin{array}{l}\text { temperature-induced } \\
\text { lipocalin }\end{array}$ & P. euphratica & ACJ02358 & 1.5 & 1.6 & -1.3 & -0.8 & -0.8 & -0.9 & 1.2 & $26 / 5.66$ & $22 / 5.72$ & 573 & 39 & $22 / 7$ & $22 / 7$ & 2.98 \\
\hline 367 & $\begin{array}{l}\text { Cu-Zn-superoxide } \\
\text { dismutase }\end{array}$ & $\begin{array}{l}\text { Populus } \\
\text { tremulax } \\
\text { Populus } \\
\text { tremuloides }\end{array}$ & CAC33844 & -0.4 & 0.2 & 0.6 & -0.1 & 0.0 & 0.2 & 0.3 & $26 / 5.75$ & $22 / 6.23$ & 2278 & 51 & $31 / 8$ & $8 / 3$ & 3.67 \\
\hline 324 & $\begin{array}{l}\text { late embryogenesis } \\
\text { abundant protein D-29 }\end{array}$ & P. trichocarpa & XP_024466770 & 0.1 & -0.1 & 0.6 & 0.1 & -0.4 & 0.1 & 0.2 & $51 / 4.97$ & $33 / 5.11$ & 1383 & 46 & $28 / 17$ & $14 / 12$ & 9.26 \\
\hline 354 & legumin family protein & P. trichocarpa & XP_002307645 & -0.3 & 0.7 & -0.1 & 0.0 & 0.0 & 0.0 & -0.4 & $27 / 6.50$ & $54 / 8.16$ & 1062 & 29 & $54 / 9$ & $5 / 2$ & 1.01 \\
\hline \multicolumn{18}{|c|}{ Reproduction } \\
\hline 336 & protein CDI & P. trichocarpa & XP_002325449 & 1.2 & 0.9 & 0.7 & 0.9 & 0.7 & -0.4 & 0.4 & $39 / 5.89$ & $30 / 5.48$ & 555 & 26 & $7 / 5$ & $3 / 2$ & 1.05 \\
\hline \multicolumn{18}{|c|}{ Unclassified } \\
\hline 35 & $\begin{array}{l}\text { universal stress protein A- } \\
\text { like protein }\end{array}$ & P. trichocarpa & XP_002324004 & -0.2 & 0.8 & -0.4 & 0.2 & -0.5 & -0.2 & -0.1 & $25 / 6.33$ & $20 / 5.97$ & 652 & 44 & $23 / 10$ & $12 / 5$ & 9.36 \\
\hline
\end{tabular}

${ }^{a}$ The spot number is as indicated on the reference gel

${ }^{b}$ The proteins identified in the present study. Protein identification was based on the best hit in a MASCOT search against NCBI databases ${ }^{\mathrm{c}} \mathrm{NCBI}$ accession numbers

${ }^{\mathrm{d}}$ Fold change calculated as $\log _{2}$ ratio (variant to control). Statistically significant changes (ANOVA and Tukey-Kramer HSD test, $p<0.05$ ) were marked in green for proteins, the abundance of which increased, and in red for proteins, the abundance of which decreased

${ }^{\mathrm{e}}$ Percentage of sequence coverage

${ }^{\mathrm{f}}$ The number of all to non-redundant peptides for the each protein spot

${ }^{\mathrm{g}}$ The number of unique to non-redundant sequences within unique peptides number

${ }^{\mathrm{h}}$ Exponentially Modified Protein Abundance Index

${ }^{\mathrm{i}}$ Functional protein classification according to biological process (GO annotation) 
decreased in abundance). Among 25 proteins responsive to $3{ }^{\circ} \mathrm{C}, 15$ were only responsive to this temperature (Fig. 3). Six proteins were only responsive to $-3{ }^{\circ} \mathrm{C}, 5$ only to $20^{\circ} \mathrm{C}$, and none only to $\mathrm{LN}$. Only 2 proteins were responsive to all temperatures.

As listed in Table 1, the spots represented 37 nonredundant proteins. The percentage of sequence coverage ranged from 7 to $61 \%$, and the number of identified peptides varied from 4 to 76 . Among the 37 spots, 23 corresponded to P. trichocarpa, 9 to other Populus family species, 4 to other woody plants, and 1 to annual plants. Homologous proteins were found for all of the spots.

To further understand the biological regulations and functions of identified proteins in storability of black poplar seeds, we carried out gene ontology (GO) and subcellular localization analyses (https://www.ebi.ac.uk/QuickGO/). The results of biological process analysis showed that a large number of identified proteins were associated with cellular process (28 proteins), metabolic process (27 proteins), and response to stimulus (14 proteins) (Table 2). The results of molecular function analysis showed that the majority of proteins was related to catalytic activity ( 24 proteins) and binding ( 20 proteins). The determination of subcellular localization showed that a large number of identified proteins were present in the cytosol (13 proteins), chloroplast (10 proteins), and mitochondria (9 proteins).

\section{Discussion}

Since seed storage is often accompanied by a progressive loss of germination vigour, storage conditions must be optimized for the preservation of genetic resources (Rajjou et al. 2008). Seed storage temperature and time of storage affect black poplar seed storability (Suszka et al. 2014). Desiccated seeds (7.1\% MC) can be stored successfully at $-3,-20{ }^{\circ} \mathrm{C}$, and -

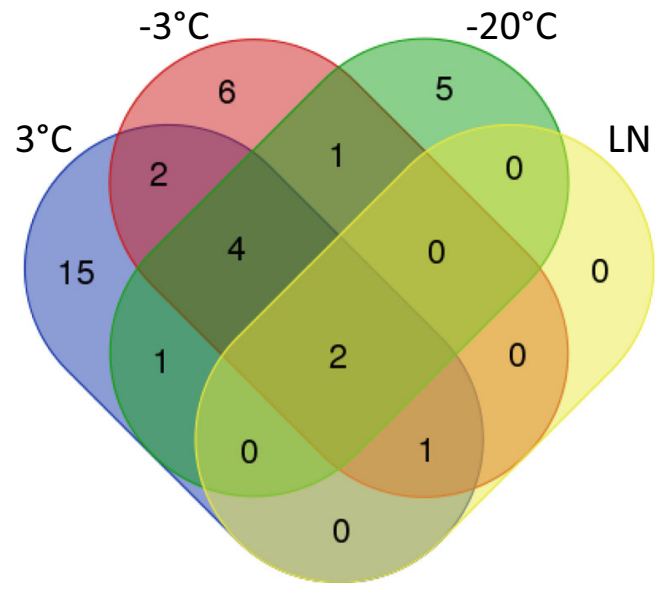

Fig. 3 Venn diagram of the 37 identified proteins grouped based on Populus nigra L. seed storage temperature of $3,-3,-20$, and $-196^{\circ} \mathrm{C}$
$196{ }^{\circ} \mathrm{C}$ for at least 2 years. These results are in agreement with the observation that low seed moisture content, low temperature, or cryopreservation result in an increase in storage life span (Walters 2004; Walters et al. 2004). A significant decrease in black poplar seed germination was observed already after 1 year of storage at $3{ }^{\circ} \mathrm{C}$. Thus, a positive temperature implicated loss of seed viability. Proteomic analysis revealed that this loss in seed vigour is accompanied by protein changes. Storage at temperature of $3{ }^{\circ} \mathrm{C}$ influenced accumulation of most (25) proteins. With lower storage temperature, the abundance of fewer proteins changed, and cryopreservation in liquid nitrogen influenced only three proteins. Gao et al. (2016) showed that seeds from rice cultivars sensitive to storage also displayed more differentially abundant proteins, in agreement with the present results.

Here, we discuss the role of the proteins that can contribute to the storability of the seeds in relation to system biology approaches (Staszak and Pawłowski 2012).

\subsection{Proteins involved in metabolism processes}

Metabolism-related proteins, particularly those involved in the carbohydrate metabolic pathways, accumulate in mature dry seeds (Fu et al. 2011; He and Yang 2013; Han and Yang 2015). An increase in seed storage temperature results in rapid resumption of several metabolic activities such as respiration, enzymatic activity, RNA, and protein synthesis (Yang et al. 2007; He et al. 2011; Kolodziejczyk et al. 2016). For germination, energy is primarily supplemented by glycolysis and fermentation followed by the tricarboxylic acid (TCA) cycle, gluconeogenesis and glyoxylate cycle, and pentose phosphate pathway (Jin et al. 2014; He and Yang 2013). The abundance of enolase (spot 140), an enzyme of the glycolysis/ gluconeogenesis pathway, and pyruvate dehydrogenase (spot 45), an enzyme linking glycolysis to the TCA cycle, was highest after storage at $3{ }^{\circ} \mathrm{C}$, and lowered with decreasing of storage temperature. A negative $\left(-20{ }^{\circ} \mathrm{C}\right)$ temperatureassociated decrease in protein abundance was also observed for glyceraldehyde-3-phosphate dehydrogenase (spots 80 and 303), an enzyme of the glycolysis/gluconeogenesis pathway. A protein related to photosynthesis (carbon fixation in pentose phosphate cycle), ribulose-1,5-bisphosphate carboxylase/ oxygenase (spot 368), decreased in abundance during storage at $-20{ }^{\circ} \mathrm{C}$. This suggests that negative storage temperatures prevent launching synthesis of energy, and in this way preserve metabolic activity until the end of storage to allow appropriate germination. Fructose-bisphosphate aldolase (spots 61 and 62), an enzyme involved in the pentose phosphate cycle as well as in glycolysis/gluconeogenesis, decreased in abundance during storage. In conclusion, energy- and carbohydrate metabolism-related enzyme synthesis is putatively blocked in temperatures below zero, which suggests that these are appropriate conditions for black poplar seed storability. 
Table 2 Gene ontology (GO) functional annotation of the identified proteins based on biological process, molecular function, and subcellular localization

\begin{tabular}{|c|c|c|}
\hline Classification & Annotation terms & No. of protein \\
\hline \multirow[t]{10}{*}{ Biological process } & Cellular process & 28 \\
\hline & Metabolic process & 27 \\
\hline & Response to stimulus & 14 \\
\hline & Biological regulation & 8 \\
\hline & Reproduction & 5 \\
\hline & Cellular component organization or biogenesis & 4 \\
\hline & Developmental process & 4 \\
\hline & Localization & 3 \\
\hline & Multicellular organism development & 3 \\
\hline & Unknown & 1 \\
\hline \multirow[t]{6}{*}{ Molecular function } & Catalytic activity & 24 \\
\hline & Binding & 20 \\
\hline & Nutrient reservoir activity & 3 \\
\hline & Structural molecule activity & 2 \\
\hline & Transporter activity & 2 \\
\hline & Unknown & 2 \\
\hline \multirow[t]{16}{*}{ Subcellular localization } & Cytosol & 13 \\
\hline & Chloroplast & 10 \\
\hline & Mitochondrion & 9 \\
\hline & Cytoplasm & 8 \\
\hline & Plasma membrane & 6 \\
\hline & Nucleus & 6 \\
\hline & Golgi apparatus & 4 \\
\hline & Vacuole & 4 \\
\hline & Endoplasmic reticulum & 3 \\
\hline & Apoplast & 2 \\
\hline & Plasmodesma & 3 \\
\hline & Cell wall & 1 \\
\hline & Extracellular region & 1 \\
\hline & Peroxisome & 1 \\
\hline & Plastid & 1 \\
\hline & Unknown & 2 \\
\hline
\end{tabular}

Enoyl-ACP reductase (83) is an enzyme of fatty acid biosynthesis and catalyzes the last step of fatty acid elongation, in which enoyl-ACP is reduced to fully saturated acyl-ACP (Massengo-Tiassé and Cronan 2009). Its abundance increased at $3{ }^{\circ} \mathrm{C}$. It can be suggested that temperature above zero triggers some metabolic activity but this, probably due to storage reserves consumption, causes a loss of seed viability.

Level of GDSL esterase/lipase (spot 351) was the lowest after storage at a temperature of $-3{ }^{\circ} \mathrm{C}$. Enzymes of the SGNH plant lipase superfamily hydrolyse ester bonds, e.g. of phospholipids, or fatty acyl esters (Teutschbein et al. 2010). A number of SGNH family lipases have been characterised, which participate in plant development and morphogenesis, plant tolerance to environmental stresses, and the metabolism of cutin and wax (Volokita et al. 2011).
They can play some role during Brassicaceae seed germination, catalyzing hydrolysis of sinapine (Clauß et al. 2008). It was also hypothesised that these lipases are related to the supply of a carbon source to the embryo through the breakdown of oil/lipid in the endosperm during seed development (Kondou et al. 2008). The role of SGNH plant esterase/lipase in storability of black poplar seeds is unknown; however, it may be associated with low temperature inhibition of hydrolysing activity.

\subsection{Proteins involved in stress responses}

ROS are continuously generated within living systems, and the inability to manage ROS load leads to elevated oxidative stress and cell damage (Møller et al. 2007). Oxidative stress 
increases during black poplar seed storage at the non-freezing temperatures, resulting in a loss of viability (Kalemba et al. 2015). Oxidative stress is coupled to the oxidative degradation of lipid membranes, also known as lipid peroxidation. This process generates over 200 types of aldehydes, many of which are highly reactive and toxic. Aldehyde dehydrogenases (ALDHs, spot 107) metabolize endogenous and exogenous aldehydes and thereby mitigate oxidative stress in organisms (Singh et al. 2013). In our experiments, the abundance of ALDH decreased during storage, reaching a minimum after 12 months of storage at $3{ }^{\circ} \mathrm{C}$, and after 24 months at $-3{ }^{\circ} \mathrm{C}$. The role of rice ALDH7 was illustrated for seed maturation by participation in desiccation tolerance and viability maintenance by detoxifying aldehydes generated by lipid peroxidation (Shin et al. 2009). A decrease in ALDH accumulation in stored black poplar seeds suggests the reduction of seed metabolic activity, and lipid peroxidation but that was not associated with seed viability.

Superoxide dismutase (Cu-Zn SOD, spot 367) takes part in conversion of superoxide to hydrogen peroxide, which is removed by glutathione peroxidase or catalase (Kwasigroch et al. 2008). Overexpression of $\mathrm{Cu}-\mathrm{Zn}$-SOD genes in tobacco seeds improved seed longevity and germination by attenuating the effects of oxidative stress produced by elongated storage conditions and harsh environmental stresses (Lee et al. 2010). It was suggested that loss of seed viability with ageing is associated with a decrease in SOD activity (Lehner et al. 2008; Bao et al. 2011; Xia et al. 2015; Sahu et al. 2017b). In the present study, Cu-Zn SOD level decreased at $3{ }^{\circ} \mathrm{C}$, which is in agreement with the above results; however, it increased only at $3{ }^{\circ} \mathrm{C}$ after 12 months of storage. Such changes are difficult to explain, but it is worth pointing out that also in some studies SOD was not directly associated with seed longevity (Bailly et al. 2002; Donà et al. 2013; Kong et al. 2015; Araldi et al. 2016). In the recalcitrant Jatropha curcas L. seeds, the activity of SOD was the lowest at the optimal storage temperature of $4{ }^{\circ} \mathrm{C}$, although at unfavourable temperatures below zero it increased (Gao et al. 2015). For Araucaria angustifolia (Bertol.) Kuntze, SOD activity was low in seeds exposed to 5 and $18{ }^{\circ} \mathrm{C}$, although at unfavourable room temperatures SOD activity initially increased but afterwards fell (Garcia et al. 2015). Initial increasing in SOD activity in the ageing seeds was associated with the accumulation of $\mathrm{H}_{2} \mathrm{O}_{2}$ (Sahu et al. 2017a), which was not sufficient for the recovery, and probably with seed deterioration progress SOD was degraded, as is also suggested for black poplar seed $\mathrm{Cu}-\mathrm{Zn}$ SOD.

Glutaredoxin C4 (class I GRX, spot 327) reached its highest abundance after 12 months at $3{ }^{\circ} \mathrm{C}$. GRXs are small ubiquitous redox enzymes involved in the reduction of oxidative modifications using glutathione (Zaffagnini et al. 2011; Ströher and Millar 2012). GRX may act as a stress-related redox regulator by maintaining the glutathionylation of its target proteins (Couturier et al. 2013). Class I GRXs represent the major enzymes responsible for protein deglutathionylation (Couturier et al. 2013). In the present study, the enzyme promoting glutathionylation, glutathione S-transferase (GST, their abundance increased during storage, most significantly at $3{ }^{\circ} \mathrm{C}($ spot 333$)$ and only significantly at $\left.3{ }^{\circ} \mathrm{C}(\operatorname{spot} 343)\right)$, has also been identified. Plant GSTs have the ability to confer tolerance against biotic and abiotic stresses by conjugation of reactive electrophile species with glutathione and the modulation of cellular redox status, biosynthesis, binding, and transport of secondary metabolites and hormones (NianiouObeidat et al. 2017). Glutathionylation itself is a posttranslational modification which can constitute an intermediate of some reactions, and can modulate protein function, serve as a signalling factor, and protect cysteine residues from irreversible oxidation (Zaffagnini et al. 2011). High abundance of these enzymes was indicated during black poplar seed storage, particularly at temperatures above zero, suggesting that GRX and GST have a role in oxidative stress protection, and in maintaining redox homeostasis. Their activity, however, was not sufficient to protect the seeds, which resulted in a decrease in germination ability. It cannot be excluded that due to protein glutathionylation/deglutathionylation cycling, these enzymes may be able to regulate developmental events associated with seed quality.

Abundance of two temperature-induced lipocalins (TILs) changed significantly after storage at $3{ }^{\circ} \mathrm{C}$ (spot 204, increased) and at 3 and $-3{ }^{\circ} \mathrm{C}$ and in $\mathrm{LN}$ (spot 356 , decreased). Lipocalins participate in the transfer of small, hydrophobic molecules. They play an important role in the regulation of developmental processes and are also involved in the reactions of organisms to various stress factors (Grzyb et al. 2006). TILs were recognized to be responsible for cold and heat tolerance by lipid protection (Kawamura and Uemura 2003; Chi et al. 2009). Arabidopsis TIL knockout plants accumulated high level of ROS, while TIL overexpression enhanced tolerance to freezing (Charron et al. 2008). Boca et al. (2014) showed that the Arabidopsis lipocalins AtTIL and AtCHL have overlapping functions essential for lipid protection and seed longevity. The present results show however that TILs were not directly associated with seed longevity.

One of the proteins, the abundance of which is increased during seed storage at $3{ }^{\circ} \mathrm{C}$, was isoflavone reductase (IFR, spot 77). This enzyme is involved in the biosynthesis of various plant defence-related phenylpropanoid-derived compounds, e.g. lignans and isoflavonoids (Gang et al. 1999). A role for the IFRs might be a part of the defence mechanism against oxidative stress because the IFRs contain an NADPH-binding domain related to oxidation/ reduction properties (Kim et al. 2010; Cheng et al. 2015). The highest presence of this enzyme in black poplar seeds at temperatures above zero implies its defence role in these adverse storage conditions. Its activity, however, was not sufficient to prevent seed deterioration. 
Different late embryogenesis abundant (LEA) proteins were found in the present study. Abundance of the dehydrin DHN 3 (LEA 2 type, spot 323) increased generally during seed storage. LEA D-29 (LEA 3, spot 324) level increased at $-3{ }^{\circ} \mathrm{C}$, besides PM22 (LEA 2, spot 337 ) at $3{ }^{\circ} \mathrm{C}$. LEA proteins are associated mainly with water deficit tolerance, due to protein protection, membrane stabilisation, and ion sequestration (Battaglia and Covarrubias 2013). They are also involved in seed development, playing a protective role during maturation drying (Kleinwächter et al. 2014). Hundertmark et al. (2011) showed that seed-specific dehydrins play a role against deterioration during storage at low moisture content. RAB18 protein (LEA 2 group) was indicated to be involved in protection of seeds against artificial ageing, suggesting its involvement in seed longevity (Rajjou et al. 2008). Several LEA proteins, including the dehydrin family, were found to be involved in dry storage survival of rice seeds (Galland et al. 2017). The role of LEA proteins in maintaining black poplar seed longevity could be associated with protecting long-term stability of dehydrated tissues.

Abundance of universal stress protein PHOS32 (USP, spot 338) increased after 1 year of storage at $3{ }^{\circ} \mathrm{C}$, besides abundance of USP A-like protein (spot 35) decreased after 1 year of storage at $3{ }^{\circ} \mathrm{C}$. The physiological function of USP in plant has remained unclear. The USP gene expression analysis showed that it is stimulated by a wide variety of stresses, including salt, osmotic stress, wounding, anoxia, and drought (Shinozaki and Yamaguchi-Shinozaki 2007, Isokpehi et al. 2011). It was found that AtUSP functions as a molecular chaperone under oxidative, heat, and cold-shock conditions (Jung et al. 2015; Melencion et al. 2017). Gorshkova et al. (2018) indicated that AtUSP is regulated by phytohormones and is involved in seed germination of Arabidopsis. The role of USPs in maintaining black poplar seed longevity could be associated with chaperon activity, but that should be verified in future experiments.

\subsection{Proteins involved in protein turnover}

Subtilisin-like protease SBT3.3 (subtilase, spot 10) increased during storage at $3{ }^{\circ} \mathrm{C}$. Subtilases are one of the largest protease families playing a critical role in protein degradation, but also in developmental regulation through protein processing (Schaller et al. 2012). With a broad spectrum of biological functions, subtilases have been gaining increasing attention with regard to their involvement in plant defence (Figueiredo et al. 2017). One of them, senescence-associated subtilase, was involved in reproductive development and determination of silique number in Arabidopsis (Martinez et al. 2015). Subtilases are essential also for seed germination by involvement in cell wall modification (Rautengarten et al. 2008). The present data suggest that in less favourable conditions for seed storage, the role of subtilase can be associated with protein degradation.

Since most plant proteases assume regulatory functions, it is of utmost importance to keep their activity under tight control (Rustgi et al. 2017). To make the regulation highly stringent and specific, plants evolved in terms of protease inhibitors, another layer of control. Kunitz-type protease inhibitors (spot 22 , increased at $3{ }^{\circ} \mathrm{C}$ ) are widespread in the plant realm. They reversibly interact with their target proteases, inhibiting their catalytic activities. Biological significance of protease and protease inhibitors interactions is very high and concerns many aspects of plant development including mobilization of storage proteins, biotic and abiotic stress tolerance, and hormone signalling (Rustgi et al. 2017). Kunitz inhibitors inhibited $\alpha$-amylase/subtilase involved in mobilization of storage carbohydrates during seed germination (Nielsen et al. 2003; Grosse-Holz and van der Hoorn 2016). During seed storage this mechanism contributes probably in maintaining homeostasis in protein turnover.

Chaperonins fold nascent proteins as well as salvage and recycle stress-denatured proteins (Saibil 2013). Type I chaperonins function as an efficient protein-folding machine, known in plants as chaperonin 60 (Cpn60)-Cpn10 in chloroplasts and heat shock protein 60 (Hsp60)-Hsp10 in mitochondria (see for review Vitlin Gruber et al. 2013). Chaperonins play a part in chloroplast biogenesis (Cpn60), protecting Rubisco activase from thermal denaturation (Cpn60) and ABA signalling (Cpn20) (Vitlin Gruber et al. 2013). The $20 \mathrm{kDa}$ chaperonin protein (spot 353) abundance was the lowest in black poplar seeds stored for 12 months at $3{ }^{\circ} \mathrm{C}$. Abundance of two other chaperonins increased generally, chaperonin CPN60-2 (spot 361) significantly in liquid N, and chaperonin 60 (spot 363 ) in $-3{ }^{\circ} \mathrm{C}$. Increasing the accumulation of chaperonins in cold temperatures is a consequence of stress response, and it can be suggested that they are putative important factors in seed longevity.

Three other identified proteins were also associated with protein turnover. Eukaryotic translation initiation factor 3 (eIF-3, spot 64) abundance reached the lowest level during black poplar seed storage at $-3{ }^{\circ} \mathrm{C}$. It is a component of the eIF-3 complex, which is involved in protein synthesis of a specialized repertoire of mRNAs and stimulates binding of mRNA and methionyl-tRNA to the $40 \mathrm{~S}$ ribosome (Hinnebusch 2014). The eIF-3 complex specifically targets and initiates translation of a subset of mRNAs involved in cell proliferation. 60S ribosomal protein L22-1 (spot 373) is directly involved in translation activity as being a part of the ribosomal exit tunnel (Gabashvili et al. 2001). Transport protein SEC13 (spot 358) is known to be involved in transporting of secreted and membrane proteins 
out of the endoplasmic reticulum (Bhattacharya et al. 2012). The abundance of these proteins was reduced during storage of black poplar seeds for 24 months at $-20{ }^{\circ} \mathrm{C}$ and for 12 months at -3 , respectively. This implies that seed storage at temperatures below zero protect translation against undesirable activity, thus inhibiting basal metabolic activity.

\section{Conclusion}

A germination test of black poplar (Populus nigra L.) seeds showed that they are preserved well at temperatures under zero. Storage at temperature above zero caused loss of seed viability. Each storage condition induced modifications in the abundance of proteins connected to biological processes related to seed storability. The loss in seed vigour was accompanied by the most numerous changes in protein abundance. It is likely that temperatures above zero trigger some metabolic activities, but with time, such temperatures cause loss of seed viability. Storage at $3{ }^{\circ} \mathrm{C}$ also caused an increase in abundance of enzymes associated with stress defence. Their presence, however, was not sufficient to prevent seed deterioration. Good storability of seeds in freezing conditions is associated with the following: the decrease in abundance of metabolism, hydrolysing and protein turnover proteins, and the increase in abundance of proteins maintaining long-term stability of dehydrated tissue. Results of present study provide valuable information, revealing the general downregulation and upregulation of significant proteins following the varying temperatures and duration of seed storage. Overall, this data should enhance understanding of the processes associated with seed longevity. The highlighting of potentially important proteins by proteomics provides researchers with starting points for further studies where the next step will be to look at the expression and regulation of the gene encoding the protein of interest, to incorporate it into the seed longevity testing.

Acknowledgements We thank Michał Dadlez's group from Mass Spectrometry Laboratory, IBB PAS, Warsaw, Poland, for the MS analyses, and Sylwia Masłowska for technical support.

Funding information This study was supported by the National Science Centre, Poland (grant number N N309 429 138)

Data availability The datasets generated during and/or analysed during the current study are available in the Zenodo repository (Pawłowski et al. 2019) at https://zenodo.org/record/3384725\#.XW5dC0fgphE.

\section{Compliance with ethical standards}

Conflict of interest The authors declare that they have no conflict of interest.
Open Access This article is distributed under the terms of the Creative Commons Attribution 4.0 International License (http:// creativecommons.org/licenses/by/4.0/), which permits unrestricted use, distribution, and reproduction in any medium, provided you give appropriate credit to the original author(s) and the source, provide a link to the Creative Commons license, and indicate if changes were made.

\section{References}

Araldi CG, Coelho CMM, Gaziola SA, Azevedo RA (2016) Storage elicits a fast antioxidant enzyme activity in Araucaria angustifolia embryos. Acta Physiol Plant 38:201. https://doi.org/10.1007/ s11738-016-2219-2

Baginsky S (2009) Plant proteomics: concepts, applications, and novel strategies for data interpretation. Mass Spectrom Rev 28:93-120. https://doi.org/10.1002/mas.20183

Bailly C, Bogatek-Leszczynska R, Côme D, Corbineau F (2002) Changes in activities of antioxidant enzymes and lipoxygenase during growth of sunflower seedlings from seeds of different vigour. Seed Sci Res 12:47-55. https://doi.org/10.1079/SSR200197

Bao J, Sha S, Zhang S (2011) Changes in germinability, lipid peroxidation, and antioxidant enzyme activities in pear stock (Pyrus betulaefolia Bge.) seeds during room- and low-temperature storage. Acta Physiol Plant 33:2035-2040. https://doi.org/10.1007/s11738011-0728-6

Battaglia M, Covarrubias AA (2013) Late embryogenesis abundant (LEA) proteins in legumes. Front Plant Sci 4. https://doi.org/10. 3389/fpls.2013.00190

Bhattacharya N, O’Donnell J, Stagg SM (2012) The structure of the Sec13/31 COPII cage bound to Sec23. J Mol Biol 420:324-334. https://doi.org/10.1016/j.jmb.2012.04.024

Boca S, Koestler F, Ksas B et al (2014) Arabidopsis lipocalins AtCHL and AtTIL have distinct but overlapping functions essential for lipid protection and seed longevity. Plant Cell Environ 37:368-381. https://doi.org/10.1111/pce.12159

Charron J-BF, Ouellet F, Houde M, Sarhan F (2008) The plant apolipoprotein $\mathrm{D}$ ortholog protects Arabidopsis against oxidative stress. BMC Plant Biol 8:86. https://doi.org/10.1186/1471-2229-8-86

Chen L, Chen Q, Kong L et al (2016) Proteomic and physiological analysis of the response of oat (Avena sativa) seeds to heat stress under different moisture conditions. Front Plant Sci 7. https://doi.org/10. 3389/fpls.2016.00896

Cheng Q, Li N, Dong L et al (2015) Overexpression of soybean isoflavone reductase (GmIFR) enhances resistance to Phytophthora sojae in soybean. Front Plant Sci 6. https://doi.org/10.3389/fpls.2015. 01024

Chi W-T, Fung RWM, Liu H-C et al (2009) Temperature-induced lipocalin is required for basal and acquired thermotolerance in Arabidopsis. Plant Cell Environ 32:917-927. https://doi.org/10. 1111/j.1365-3040.2009.01972.x

Clauß K, Baumert A, Nimtz M et al (2008) Role of a GDSL lipase-like protein as sinapine esterase in Brassicaceae. Plant J 53:802-813. https://doi.org/10.1111/j.1365-313X.2007.03374.x

Couturier J, Jacquot J-P, Rouhier N (2013) Toward a refined classification of class I dithiol glutaredoxins from poplar: biochemical basis for the definition of two subclasses. Front Plant Sci:4. https://doi.org/10. 3389/fpls.2013.00518

Donà M, Balestrazzi A, Mondoni A et al (2013) DNA profiling, telomere analysis and antioxidant properties as tools for monitoring ex situ seed longevity. Ann Bot 111:987-998. https://doi.org/10.1093/aob/ met058 
Figueiredo J, Sousa Silva M, Figueiredo A (2017) Subtilisin-like proteases in plant defence: the past, the present and beyond. Mol Plant Pathol n/a-n/a https://doi.org/10.1111/mpp.12567

Fu YB, Ahmed Z, Diederichsen A. (2015) Towards a better monitoring of seed ageing under ex situ seed conservation. Conserv Physiol 3: cov026. https://doi.org/10.1093/conphys/cov026

Gabashvili IS, Gregory ST, Valle M et al (2001) The polypeptide tunnel system in the ribosome and its gating in erythromycin resistance mutants of L4 and L22. Mol Cell 8:181-188. https://doi.org/10. 1016/S1097-2765(01)00293-3

Galland M, He D, Lounifi I et al (2017) An integrated "multi-omics" comparison of embryo and endosperm tissue-specific features and their impact on rice seed quality. Front Plant Sci 8. https://doi.org/10. 3389/fpls.2017.01984

Gang DR, Kasahara H, Xia ZQ et al (1999) Evolution of plant defense mechanisms. Relationships of phenylcoumaran benzylic ether reductases to pinoresinol-lariciresinol and isoflavone reductases. J Biol Chem 274:7516-7527

Gao S, Yan R, Chen F (2015) Effects of different storage temperatures and times on germination and antioxidant responses of Jatropha curcas seeds. J Agric Sci Technol 17:1619-1628

Gao J, Fu H, Zhou X et al (2016) Comparative proteomic analysis of seed embryo proteins associated with seed storability in rice (Oryza sativa L) during natural aging. Plant Physiol Biochem 103:31-44. https:// doi.org/10.1016/j.plaphy.2016.02.026

Garcia C, Medeiros Coelho CM, Maraschin M et al (2015) Biochemical changes in Araucaria angustifolia (Araucariaceae) zygotic embryos during the storage. Rev Biol Trop 63

Gorshkova DS, Getman IA, Voronkov AS et al (2018) The gene encoding the universal stress protein AtUSP is regulated by phytohormones and involved in seed germination of Arabidopsis thaliana. Dokl Biochem Biophys 479:105-107. https://doi.org/10.1134/ S1607672918020151

Grosse-Holz FM, van der Hoorn RAL (2016) Juggling jobs: roles and mechanisms of multifunctional protease inhibitors in plants. New Phytol 210:794-807. https://doi.org/10.1111/nph.13839

Grzyb J, Latowski D, Strzałka K (2006) Lipocalins - a family portrait. J Plant Physiol 163:895-915. https://doi.org/10.1016/j.jplph.2005.12. 007

Han C, Yang P (2015) Studies on the molecular mechanisms of seed germination. Proteomics 15:1671-1679. https://doi.org/10.1002/ pmic. 201400375

He D, Han C, Yang P. (2011) Gene expression profile changes in germinating rice. J Integr Plant Biol 53: 835-44. https://doi.org/10.1111/j. 1744-7909.2011.01074.x

He D, Yang P (2013) Proteomics of rice seed germination. Front Plant Sci:4. https://doi.org/10.3389/fpls.2013.00246

Hinnebusch AG (2014) The scanning mechanism of eukaryotic translation initiation. Annu Rev Biochem 83:779-812. https://doi.org/10. 1146/annurev-biochem-060713-035802

Hundertmark M, Buitink J, Leprince O, Hincha DK (2011) The reduction of seed-specific dehydrins reduces seed longevity in Arabidopsis thaliana. Seed Sci Res 21:165-173. https://doi.org/10.1017/ S0960258511000079

Isokpehi RD, Simmons SS, Cohly HHP et al (2011) Identification of drought-responsive universal stress proteins in viridiplantae. Bioinform Biol Insights 5:41-58. https://doi.org/10.4137/BBI. S6061

ISTA (2013) ISTA: International rules for seed testing. Edition 2006. International Seed Testing Association, Bassersdorf

Jin X, Fu Z, Ding D et al (2014) Proteomic analysis of plumules and coleoptiles in maize between hybrids and their corresponding inbred lines. Acta Physiol Plant 36:355-370. https://doi.org/10.1007/ s11738-013-1417-4

Jung YJ, Melencion SMB, Lee ES et al (2015) Universal stress protein exhibits a redox-dependent chaperone function in Arabidopsis and enhances plant tolerance to heat shock and oxidative stress. Front Plant Sci 6:1141. https://doi.org/10.3389/fpls.2015.01141

Kalemba EM, Pukacka S (2014) Carbonylated proteins accumulated as vitality decreases during long-term storage of beech (Fagus sylvatica L.) seeds. Trees 28:503-515. https://doi.org/10.1007/s00468-0130967-9

Kalemba EM, Suszka J, Ratajczak E (2015) The role of oxidative stress in determining the level of viability of black poplar (Populus nigra) seeds stored at different temperatures. Funct Plant Biol 42:630-642. https://doi.org/10.1071/FP14336

Kawamura Y, Uemura M (2003) Mass spectrometric approach for identifying putative plasma membrane proteins of Arabidopsis leaves associated with cold acclimation. Plant J 36:141-154. https://doi. org/10.1046/j.1365-313X.2003.01864.x

Kim SG, Kim ST, Wang Y et al (2010) Overexpression of rice isoflavone reductase-like gene (OsIRL) confers tolerance to reactive oxygen species. Physiol Plant 138:1-9. https://doi.org/10.1111/j.13993054.2009.01290.x

Kleinwächter M, Radwan A, Hara M, Selmar D (2014) Dehydrin expression in seeds: an issue of maturation drying. Front Plant Sci 5. https://doi.org/10.3389/fpls.2014.00402

Kołodziejczyk I, Dzitko K, Szewczyk R, Posmyk MM.J (2016) Exogenous melatonin improves corn (Zea mays L.) embryo proteome in seeds subjected to chilling stress. Plant Physiol 193: 47-56. https://doi.org/10.1016/j.jplph.2016.01.012

Kondou Y, Nakazawa M, Kawashima M et al (2008) RETARDED GROWTH OF EMBRYO1, a new basic helix-loop-helix protein, expresses in endosperm to control embryo growth. Plant Physiol 147:1924-1935. https://doi.org/10.1104/pp.108.118364

Kong L, Huo H, Mao P (2015) Antioxidant response and related gene expression in aged oat seed. Front Plant Sci:6. https://doi.org/10. 3389/fpls.2015.00158

Kwasigroch JM, Wintjens R, Gilis D, Rooman M (2008) SODa: An Mn/ $\mathrm{Fe}$ superoxide dismutase prediction and design server. BMC Bioinformatics 9:257. https://doi.org/10.1186/1471-2105-9-257

Lee YP, Baek K-H, Lee H-S et al (2010) Tobacco seeds simultaneously over-expressing $\mathrm{Cu} / \mathrm{Zn}$-superoxide dismutase and ascorbate peroxidase display enhanced seed longevity and germination rates under stress conditions. J Exp Bot 61:2499-2506. https://doi.org/10.1093/ $\mathrm{jxb} / \mathrm{erq} 085$

Lehner A, Mamadou N, Poels P et al (2008) Changes in soluble carbohydrates, lipid peroxidation and antioxidant enzyme activities in the embryo during ageing in wheat grains. J Cereal Sci 47:555-565. https://doi.org/10.1016/j.jcs.2007.06.017

Li Y, Wang Y, Xue H et al (2017) Changes in the mitochondrial protein profile due to ROS eruption during ageing of elm (Ulmus pumila L.) seeds. Plant Physiol Biochem 114:72-87. https://doi.org/10.1016/j. plaphy.2017.02.023

Martinez DE, Borniego ML, Battchikova N et al (2015) SASP, a senescence-associated subtilisin protease, is involved in reproductive development and determination of silique number in Arabidopsis. J Exp Bot 66:161-174. https://doi.org/10.1093/jxb/ eru409

Massengo-Tiassé RP, Cronan JE (2009) Diversity in enoyl-acyl carrier protein reductases. Cell Mol Life Sci 66:1507-1517. https://doi.org/ 10.1007/s00018-009-8704-7

Melencion SMB, Chi YH, Pham TT et al (2017) RNA chaperone function of a universal stress protein in Arabidopsis confers enhanced cold stress tolerance in plants. Int J Mol Sci 18:2546. https://doi.org/ 10.3390/ijms 18122546

Meunier B, Bouley J, Piec I, Bernard C, Picard B, Hocquette JF. (2005) Data analysis methods for detection of differential protein expression in twodimensional gel electrophoresis. Anal Biochem 340: 226-30. https://doi.org/10.1016/j.ab.2005.02.028

Michalak M, Plitta BP, Tylkowski T et al (2015) Desiccation tolerance and cryopreservation of seeds of black poplar (Populus nigra L.), a 
disappearing tree species in Europe. Eur J Forest Res 134:53-60. https://doi.org/10.1007/s10342-014-0832-4

Min CW, Lee SH, Cheon YE et al (2017) In-depth proteomic analysis of Glycine max seeds during controlled deterioration treatment reveals a shift in seed metabolism. J Proteome 169:125-135. https://doi.org/ 10.1016/j.jprot.2017.06.022

Møller IM, Jensen PE, Hansson A (2007) Oxidative modifications to cellular components in plants. Annu Rev Plant Biol 58:459-481. https://doi.org/10.1146/annurev.arplant.58.032806.103946

Neuhoff V, Arold N, Taube D, Ehrhardt W (1988) Improved staining of proteins in polyacrylamide gels including isoelectric focusing gels with clear background at nanogram sensitivity using Coomassie Brilliant Blue G-250 and R-250. Electrophoresis 9:255-262. https://doi.org/10.1002/elps.1150090603

Nguyen T-P, Cueff G, Hegedus DD et al (2015) A role for seed storage proteins in Arabidopsis seed longevity. J Exp Bot 66:6399-6413. https://doi.org/10.1093/jxb/erv348

Nianiou-Obeidat I, Madesis P, Kissoudis C et al (2017) Plant glutathione transferase-mediated stress tolerance: functions and biotechnological applications. Plant Cell Rep 36:791-805. https://doi.org/10. 1007/s00299-017-2139-7

Nielsen PK, Bønsager BC, Berland CR et al (2003) Kinetics and energetics of the binding between barley alpha-amylase/subtilisin inhibitor and barley alpha-amylase 2 analyzed by surface plasmon resonance and isothermal titration calorimetry. Biochemistry 42:14781487. https://doi.org/10.1021/bi020508+

Pawłowski TA (2009) Proteome analysis of Norway maple (Acer platanoides L.) seeds dormancy breaking and germination: influence of abscisic and gibberellic acids. BMC Plant Biol 9:48. https://doi.org/10.1186/1471-2229-9-48

Pawłowski TA, Staszak AM (2016) Analysis of the embryo proteome of sycamore (Acer pseudoplatanus L.) seeds reveals a distinct class of proteins regulating dormancy release. J Plant Physiol 195:9-22. https://doi.org/10.1016/j.jplph.2016.02.017

Pawłowski TA, Klupczyńska EA, Staszak AM, Suszka J (2019) Proteomic data set of the analysis of black poplar (Populus nigra L.) seed storability. V2. Zenodo. [Dataset]. https://doi.org/10.5281/ zenodo.3384725. Accessed 01 Aug 2019

Rajjou L, Debeaujon I (2008) Seed longevity: survival and maintenance of high germination ability of dry seeds. Comptes Rendus Biologies 331:796-805. https://doi.org/10.1016/j.crvi.2008.07.021

Rajjou L, Lovigny Y, Groot SPC et al (2008) Proteome-wide characterization of seed aging in Arabidopsis: a comparison between artificial and natural aging protocols. Plant Physiol 148:620-641. https://doi. org/10.1104/pp.108.123141

Ramagli LS, Rodriguez LV (1985) Quantitation of microgram amounts of protein in two-dimensional polyacrylamide gel electrophoresis sample buffer. Electrophoresis 6:559-563. https://doi.org/10.1002/elps. 1150061109

Rautengarten C, Usadel B, Neumetzler L et al (2008) A subtilisin-like serine protease essential for mucilage release from Arabidopsis seed coats. Plant J 54:466-480. https://doi.org/10.1111/j.1365-313X. 2008.03437.x

Rustgi S, Boex-Fontvieille E, Reinbothe C et al (2017) The complex world of plant protease inhibitors: insights into a Kunitz-type cysteine protease inhibitor of Arabidopsis thaliana. Commun Integr Biol 11. https://doi.org/10.1080/19420889.2017.1368599

Sahu AK, Sahu B, Soni A, Naithani SC (2017a) Active oxygen species metabolism in neem (Azadirachta indica) seeds exposed to natural ageing and controlled deterioration. Acta Physiol Plant 39:197. https://doi.org/10.1007/s11738-017-2494-6

Sahu B, Sahu AK, Thomas V, Naithani SC (2017b) Reactive oxygen species, lipid peroxidation, protein oxidation and antioxidative enzymes in dehydrating Karanj (Pongamia pinnata) seeds during storage. S Afr J Bot 112:383-390. https://doi.org/10.1016/j.sajb.2017. 06.030
Saibil H (2013) Chaperone machines for protein folding, unfolding and disaggregation. Nat Rev Mol Cell Biol 14:630-642. https://doi.org/ 10.1038/nrm3658

Sano N, Rajjou L, North HM et al (2016) Staying alive: molecular aspects of seed longevity. Plant Cell Physiol 57:660-674. https://doi.org/10. 1093/pcp/pcv186

Schaller A, Stintzi A, Graff L (2012) Subtilases - versatile tools for protein turnover, plant development, and interactions with the environment. Physiol Plant 145:52-66. https://doi.org/10.1111/j.13993054.2011.01529.x

Shin J-H, Kim S-R, An G (2009) Rice aldehyde dehydrogenase7 is needed for seed maturation and viability. Plant Physiol 149:905-915. https://doi.org/10.1104/pp.108.130716

Shinozaki K, Yamaguchi-Shinozaki K (2007) Gene networks involved in drought stress response and tolerance. J Exp Bot 58:221-227. https://doi.org/10.1093/jxb/erl164

Singh S, Brocker C, Koppaka V et al (2013) Aldehyde dehydrogenases in cellular responses to oxidative/electrophilic stress. Free Radic Biol Med 56:89-101. https://doi.org/10.1016/j.freeradbiomed.2012.11. 010

Staszak AM, Pawłowski T (2012) Forest tree research in post genomic era. Introduction to systems biology of broadleaves. Dendrobiology 68:113-123

Staszak AM, Pawłowski TA (2014) Proteomic analysis of embryogenesis and the acquisition of seed dormancy in Norway maple (Acer platanoides L.). Int J Mol Sci 15:10868-10891. https://doi.org/10. 3390/ijms150610868

Staszak AM, Rewers M, Sliwinska E et al (2019) DNA synthesis pattern, proteome, and ABA and GA signalling in developing seeds of Norway maple (Acer platanoides). Funct Plant Biol 46:152-164. https://doi.org/10.1071/FP18074

Ströher E, Millar AH (2012) The biological roles of glutaredoxins. Biochem J 446:333-348. https://doi.org/10.1042/BJ20112131

Suszka J, Plitta BP, Michalak M et al (2014) Optimal seed water content and storage temperature for preservation of Populus nigra L. germplasm. Ann For Sci 71:543-549. https://doi.org/10.1007/s13595014-0368-2

Teutschbein J, Gross W, Nimtz M et al (2010) Identification and localization of a lipase-like acyltransferase in phenylpropanoid metabolism of tomato (Solanum lycopersicum). J Biol Chem 285:3837438381. https://doi.org/10.1074/jbc.M110.171637

van de Venter A (2001) What is seed vigour? J New Seeds 2:67-72. https://doi.org/10.1300/J153v02n03_06

Vitlin Gruber A, Nisemblat S, Azem A, Weiss C (2013) The complexity of chloroplast chaperonins. Trends Plant Sci 18:688-694. https:// doi.org/10.1016/j.tplants.2013.08.001

Volokita M, Rosilio-Brami T, Rivkin N, Zik M (2011) Combining comparative sequence and genomic data to ascertain phylogenetic relationships and explore the evolution of the large GDSL-lipase family in land plants. Mol Biol Evol 28:551-565. https://doi.org/10.1093/ molbev/msq226

Walters C (2004) Temperature dependency of molecular mobility in preserved seeds. Biophys J 86:1253-1258

Walters C, Wheeler L, Stanwood PC (2004) Longevity of cryogenically stored seeds. Cryobiology 48:229-244. https://doi.org/10.1016/j. cryobiol.2004.01.007

Wang W-Q, Liu S-J, Song S-Q, Møller IM (2015) Proteomics of seed development, desiccation tolerance, germination and vigor. Plant Physiol Biochem 86:1-15. https://doi.org/10.1016/j.plaphy.2014. 11.003

Wyckoff G, Zasada J (2005) Populus L. In: Bonner F (ed) Woody plant seed manual. Agric. Handbk. USDA Forest Service, Washington, DC, pp 856-871

Xia F, Chen L, Sun Y, Mao P (2015) Relationships between ultrastructure of embryo cells and biochemical variations during ageing of oat 
(Avena sativa L.) seeds with different moisture content. Acta Physiol Plant 37:89. https://doi.org/10.1007/s11738-015-1825-8

Yang P, Li X, Wang X, Chen H, Chen F, Shen S. (2007) Proteomic analysis of rice ( Oryza sativa) seeds during germination. Proteomics 7: 3358-68. https://doi.org/10.1002/pmic.200700207

Yin X, He D, Gupta R, Yang P (2015) Physiological and proteomic analyses on artificially aged Brassica napus seed. Front Plant Sci: 6. https://doi.org/10.3389/fpls.2015.00112

Yin G, Xin X, Fu S et al (2017) Proteomic and carbonylation profile analysis at the critical node of seed ageing in Oryza sativa. Sci Rep 7:srep40611. https://doi.org/10.1038/srep40611

Zaffagnini M, Bedhomme M, Marchand CH et al (2011) Redox regulation in photosynthetic organisms: focus on glutathionylation.
Antioxid Redox Signal 16:567-586. https://doi.org/10.1089/ars. 2011.4255

Zhang Y, Li Y (2015) Identification of heat-stable proteins in imbibed Cowpea (Vigna unguiculata) seeds. Acta Physiol Plant 37:24. https://doi.org/10.1007/s11738-015-1772-4

Zhang H, Wang W-Q, Liu S-J et al (2015) Proteome analysis of poplar seed vigor. PLoS ONE 10:e0132509. https://doi.org/10.1371/ journal.pone. 0132509

Publisher's note Springer Nature remains neutral with regard to jurisdictional claims in published maps and institutional affiliations. 